\title{
CREDITORS' SETTLEMENT OR WHEN IS IT ADVISABLE TO DEVIATE FROM THE ABSOLUTE PRIORITY RULE
}

\section{CSŐDEGYEZSÉG - AVAGY MIKOR AJÁNLOTT AZ ABSZOLÚT ELSŐBBSÉGI SZABÁLYTÓL VALÓ ELTÉRÉS}

\author{
Éva PÁliNKóa ${ }^{\mathrm{a}}$ Kinga PÉTERVÁRI ${ }^{\mathrm{a}}$ \\ a NJE Faculty of Economics and Business, 6000. Kecskemét Izsáki út 10. palinkoeva@gmail.com; \\ petervari@gti.elte.hu
}

Cite this article: Pálinkó, É., Pétervári, K. (2019). Creditors' Settlement or When Is It Advisable to Deviate from the Absolute Priority Rule. Deturope. 11(3): 264-282.

\begin{abstract}
Bankruptcies carry important information for the market. Bankruptcy rules in crisis become even more relevant since the reason of insolvency then is often not caused by the company's failure or inefficiency, but by external impacts like chain debts or the loosing of markets. So it happened in 2008 too. The balancing in the bankruptcy rules in these cases should be designed to guarantee the return of the expectations developed by the interested parties - debtors and creditors - at the time of the investment. This is the way to protect the trust of the participants in the financial markets and in the businesses. Despite many amendments the efficiency of these bankruptcy rules in Hungary, however, is not very promising. The country is ranked in the 24th place out of the 28 Member States in the EU in a World Bank survey in 2018, in which the efficiency of the solutions to the problem of insolvency was compared.

This study summarizes the results of a primary research which investigated that, although the Hungarian rules are seemingly in line with the international and regional standards and the EU regulations in reorganization matters, why is there, however, no such efficient capital allocation as it should be expected by the investors and would be necessary to reinforce the trust in the market.

The main statement of the article is that the Hungarian bankruptcy rules fail to promote the efficient capital allocation because the stakeholders have no information or are not interested - for the costs may be too high - in those financial data or parameters, which are necessary for a deliberated settlement in a bankruptcy procedure.
\end{abstract}

Keywords: bankruptcy, creditors' settlement, efficient breach of contract, Central and Eastern Europe, EU, Hungary

\begin{abstract}
Absztrakt
Minden csőd fontos információ a piacnak. A válságok idején azonban az ilyen információ még fontosabb, hiszen a fizetésképtelenség oka ilyenkor sok esetben nem a vállalati értékteremtés hiánya, hanem külső okok, mint például a lánctartozás vagy átmeneti piacvesztés. Jó példa a 2008-as pénzügyi világválság. A fizetésképtelenség szabályozása terén a verseny azért folyik, hogy egy országban olyan hitelezővédelem alakuljon ki, amely megfelel az érdekeltek - adósok és hitelezök - befektetéskori várakozásainak. Így lehet megőrizni a globális térben a tőkepiaci és üzleti szereplők bizalmát. Ebben a versenyben Magyarország, egy 2018-as világbanki besorolás szerint, az EU-ban a fizetésképtelenség problémájának megoldásában a 28 országgal összehasonlítva a 24 . helyen van.

Ez a tanulmány egy primer kutatás tapasztalatait összegezve azt vizsgálja, hogy mi a magyarázata annak, hogy bár a csődtörvény módosításai Magyarországon láthatóan követték a nemzetközi valamint a regionális trendeket és az EU rendeleteket, a pénzügyi nehézségekkel küzdő vállalkozások esetében a kínált megoldások nem vezettek olyan hatékony tökeallokációs döntésekhez, amelyek megfelelö hitelezővédelmet biztosítanának, és ezen keresztül erősítenék a tőkepiaci és üzleti szereplök bizalmát.
\end{abstract}


A tanulmány fő megállapítása, hogy a jelenlegi csődszabályok erre nem alkalmasak. A szereplök nem ismerik vagy nem érdekük megismerni - mert esetleg túl magasak a költségek - azokat a pénzügyi kritériumokat, amelyek szükségesek egy a továbbmüködést támogató egyezségi döntéshez.

Keywords: csődeljárás, csődegyezség, szerződésszegés, Közép-Kelet-Európa, EU, Magyarország

\section{INTRODUCTION}

Absolute priority rule (APR) enables the secured creditors to receive full compensation (absolute) whereas others in the queue may receive nothing (priority), because the debtor's assets do not provide enough coverage. This rule is to yield more credit for debtors by lowering the secured creditors' risk. Critics of the APR emphasise that secured creditors are not motivated to negotiate the reorganisation with non-secured creditors for a further operation of the company even if it were more efficient than final liquidation.

For avoiding the high transaction costs most of the legal orders in Europe render provisions against APR, the so called carve-out regulations. These regulations separate the debtors' assets and constrain the effectivity of the APR only partially.

The application of these rules become even more complex in case of crisis where bankruptcy is not necessarily the result of the inefficient activity of a company. In the crisis of the 1990s a more malleable system of reorganisation was promoted everywhere. The lesson has been learned from several cases, like the General Motors, Chrysler cases. The assets of a company is the most valuable in its entirety, in its producing capacity, and any piecemeal sales of it would just generate more losses (Goolsbee \& Krueger 2015). Reorganisation, especially early and possibly quick reorganisation (or a pre-pack) is a crucial issue in the procedure. Yet, if the procedure is to be so quick it may not be transparent enough and so the debtors in possession, like the management or the owners, may enrich themselves at the expense of other stakeholders not equipped with the needed information. Out of this fear there are basically no pre-pack rules in Central and Eastern Europe (McCormack et al. 2016). Swiftness is important though, because the loss of the good-will of a company in bankruptcy is extremely detrimental, which extends to further losses: the loss of customers, the loss of trained employees and loss of taxes for the local authorities.

This tendency to promote reorganisation as opposed to liquidation was reinforced during the global crisis of 2008. In a financial crisis, due to the chain debts or debt-queues, many companies end up in insolvency despite their long-term viability or otherwise value-producing activity in a longer period of time. These companies therefore need to be allowed to settle with their creditors and be able to restructure their debts. 
A World Bank Study of 2010 analysed the effectiveness of the reorganisation rules of the various countries during the crisis (Cirmizi, Klapper, \& Uttamchandani, 2010). The number of the reorganisation procedures soared all over the world in 2008. There were 13.306 reorganisations in Japan meaning 49\% more cases than in 2008 (Teikoku Databank, 2010). This number is $94.135,(5.88 \%)$ in Great Britain and 32.687 (11\%) in Germany. In the meantime, however, the volume of the debt doubled. In the USA there were 60.837 reorganisation procedures in 2008, which showed $40 \%$ growth.

These numbers in the EU were not so high since the companies received $8.3 \%$ state aid in 2009 (Temporary Framework 2008), thus only 6\% of the financially distressed companies filed for bankruptcy. The highest rate of bankruptcy $9.9 \%$ was that of Hungary (Correa \& Iootty 2010).

The following study summarizes the results of a primary research conducted between 2009 and 2014. The question was that, although the Hungarian rules are seemingly in line with the international standards in reorganization matters, why is there no such efficient capital allocation as it should be expected by the investors and would be necessary to reinforce the trust in the market.

\section{REORGANISATION AND SETTLEMENT V. LIQUIDATION / THE REASON FOR AN ABSOLUTE PRIORITY RULE}

\section{Reorganisation in the global crisis}

The institution of reorganisation is a child of the late 19th century economic crisis and its inefficient bankruptcy procedures. From this point of view, bankruptcy is a natural element in the life-cycles of capitalism. The creditors and the debtors in a bankruptcy procedure are supposed to cooperate efficiently thereby letting the economy grow.

In a crisis, however, this may not go easily, so special advisors to the World Bank in the EastAsian crisis of the 1990s, suggested the introduction of the "super Chapter 11" (Miller \& Stiglitz 1999). This was supposed to be a cure as a necessary macroeconomic shock-therapy. The aim of the "super Chapter 11" was in fact not to liquidate the financially distressed but otherwise viable companies but to motivate the creditors and debtors to settle, since individual negotiations in a crisis is costlier and difficult especially because of the inevitable rise of the free riding problem. If some creditors write off enough debts, then some others would not need so. Yet, by the force of the law the negotiations become cheaper and certain. This method however, comes at a price: contracts need to be renegotiated. 
As a result, the "super Chapter 11" helped in the crisis management in East-Asia because liquidation was not automatic and many companies could survive. Yet, it was also true, that several unviable companies could carry on for too long with their businesses even after the crisis (Claessens \& Laeven 2005).

Notwithstanding, "super Chapter 11" was certainly tainted with moral hazard (Miller \& Stiglitz 1999) ${ }^{28}$, since this crisis management necessarily protects those directors and owners who were first to be blamed for the coming about of the crisis itself (Demirguc, Laeven, \& Levine, 2009). Some argued, that albeit it is not fair, this might persuade the creditors to calculate this sort of risk. This then would raise the interest rates for all though (Klapper, Laeven, \& Rajan, 2006). Others show, that one of the criteria of economic growth is to liquidate ailing companies. Certainly, when innovation increases in a sector, then the general survival rate decreases among the companies. The actual exit of the inefficient companies from the market pushes the remaining ones to be more efficient.

Despite the fact that, seemingly, there is no consent among the academics whether or not the enhancement of reorganisation is necessary, it is true that most EU Member States have more malleable rules on bankruptcy cases than used to have. These reforms are all to impede the liquidation of still productive companies and to let non-producing companies exit as soon as possible. To reduce the costs of a bankruptcy procedure is good for the creditors, and a settlement between the creditors and the debtors may ameliorate the financial situation of the company. The experiences of the global financial crisis in 2008 are analogous with those of the East-Asian and Latin-American ones in the 1990s.

\section{When is it financially rational for the debtors and the creditors to make a settlement?}

Financially distressed companies may choose between liquidation (exit) and bankruptcy (reorganisation). Such a choice is effective when the costs and the expectations are freely deliberated. Such a decision, in a perfect market, is effective when the company ends up in reorganisation because it is capable to create profit.

The still generally used criteria for how to make a settlement in a perfect market was defined by Haugen and Senbet (1978) 40 years ago. Under such circumstances creditors, debtors and/or the owners have exactly the same and all-encompassing information as to what kind of

\footnotetext{
28 "This limit on the unanticipated transfers to the creditor could prevent industrial collapse in the borrowing country, but it raises the concerns of equity, specifically the fairness of changing the rules in mid-stream. To some degree, these claims may be outweighed by the greater imperative of maintaining production in the crisis. But "the rules" themselves are inherently ambiguous in the midst of a situation that neither party to the contract explicitly agreed upon or even envisioned.
} 
capabilities of an ailing company has in the near future. If it has, a settlement will naturally be an economically sound one. Thus, both groups of the stakeholders in the company, the debtors and the creditors, would calculate with the same information: if the liquidation value (VL) of the company is smaller than the operating value (VC) then the company should be reorganised, otherwise the company is to be liquidated. The main requirement is that no creditor should be in a worse position to restructure than he would be in a liquidation.

Table 1 The efficiency of the decision on settlement in both cases: economic efficiency and cooperation (coalition) efficiency if access to information is perfectly open

\begin{tabular}{|c|c|c|}
\hline \multirow{2}{*}{$\begin{array}{c}\text { Efficient decision on } \\
\text { settlement }\end{array}$} & economic efficiency & $\begin{array}{c}\text { cooperation (coalition) } \\
\text { efficiency }\end{array}$ \\
\cline { 2 - 3 } & \multicolumn{2}{|c|}{ Criteria } \\
\cline { 2 - 3 } & $\mathrm{V}_{\mathrm{C}}-\mathrm{V}_{\mathrm{L}}>\mathrm{R}$ & $\mathrm{V}_{\mathrm{C}}>(1-\mathrm{s}) \mathrm{D}+\mathrm{R}$ \\
\hline $\begin{array}{c}\text { settlement for reorganisation if } \\
\text { both criteria are met }\end{array}$ & \multicolumn{2}{|c|}{$\begin{array}{c}\text { If } \\
\mathrm{V}_{\mathrm{L}}=(1-\mathrm{s}) \mathrm{D} \\
\text { then }\end{array}$} \\
& \multicolumn{2}{|c|}{$\begin{array}{c}\text { And } \\
\mathrm{V}_{\mathrm{C}}>\mathrm{V}_{\mathrm{L}}+\mathrm{R}=(1-\mathrm{s}) \mathrm{D}+\mathrm{R}\end{array}$} \\
\hline & $\mathrm{V}_{\mathrm{C}}>\mathrm{V}_{\mathrm{L}}+\mathrm{R}$ & $\mathrm{V}_{\mathrm{C}}>(1-\mathrm{s}) \mathrm{D}+\mathrm{R}$ \\
\hline
\end{tabular}

Sources: according to White (1983); Ábel (1991)

Note: $\mathrm{R}=$ costs of reorganisation, $\mathrm{s}=$ the (percentage) share of the amount written off by the creditors

In practice, however, the decisions are often distorted by information asymmetry therefore there is a potential risk that value destructing companies operate further based on a credit restructuring settlement, or else a still value producing company is liquidated.

The rules however, may change the behaviour in a non-perfect market. Yet, the question, which party has less or more information, depends not only on the regulations. The interpretation of the various data requires more expertise. There has been a tendency that the shareholders and the management is more likely to choose reorganisation even if liquidation were more efficient due to the complex problem of costs and principal-agent questions. Owners and/or the management may keep their position and push the costs on to the creditors. Since information is not equally available, owners may ameliorate their financial position at the expense of the creditors. Shareholders vote for projects which they otherwise would not support if creditors would not finance them. On the other hand, the management is also interested in keeping its status so it advocates even risky investments in order to avoid bankruptcy. Therefore, creditors in defence wish to push the costs of the management to the owners. In these cases if the creditors write off certain claims, the debtor may be able to stabilise the company and restructure the debt $(\mathrm{VL}=(1-\mathrm{s}) \mathrm{D})$. 
To solve the information asymmetry problems, some support the swift sale of the ailing company on the open market and the immediate compensation of the creditors according to the absolute priority rule (Eckbo \& Thorburn 2009). The residuum will be distributed to the owners, if any $(\mathrm{VL}-\mathrm{D})$. The new owners then are the best fit to have a full informed decision on what to do with the company (this is like the Swedish mandatory auction bankruptcy procedure).

The whole debate on liquidation or reorganisation has finally been erased by the global financial crisis of 2008. Although there are many newer ideas for the efficiency of the reorganisations, the basic notion as described is still fundamental.

\section{When is it legally advisable to deviate from the APR?}

Bankruptcy laws are to enforce contracts from a strict legal point of view. Promises have to be fulfilled, if not, there are consequences. However, the idea of an efficient breach of contract is recognized ever since Justice Holmes said "the promise was to be no more than a prediction, that one must pay damages if broke his promise" (Holmes 1897). So, it can be argued, that foreseeability and prediction is salient and the access to information is by far the most important issue.

Yet, information is not equally distributed among the interested parties. Secured creditors are always better informed than the non-secured (generally commercial) creditors, the employees or the other stakeholders. Besides, although owners, shareholders, investors or creditors of the company risk their wealth, they basically have no, or much less, information about the companies' future than the directors have, because they have chosen not to have (daily) access to it. Their agents are the directors who, however, tend to have inherently different, often rather short-term, interests; therefore, directors owe special duty, the fiduciary duty, towards the company (i.e. agency problem). Hence the company laws and bankruptcy laws grant different rights to the owners (shareholders) to control the directors. The most important of those are the various obligations of the directors for disclosures, such as financial statements, balance sheets, convening the general meeting if the registered capital decreases, etc.

Early information, therefore is extremely precious. Already the threat of a compulsory disclosure could prevent certain bad investments, compelling the management to argue and deliberate. The directors' liability, the fiduciary duty (duty of care and duty of loyalty) also serve this purpose. Early information could preclude possible frauds, void contracts, like 
fraudulent conveyance, such as siphoning off the assets from the company, or other voidable contracts, such as illegally promoting certain creditors at the expense of others.

So, the basic question of bankruptcy laws is who among the interested parties can get information, when and to what extent so that to make the necessary decisions. And then what measures could be used.

The interested parties in bankruptcy procedures are extremely diverse and in case the company is in the vicinity of bankruptcy, the stakeholders' roles often change. In the European legal regime, the directors cease to be liable only to the company. In some countries, among them Hungary, already the threat of bankruptcy causes the directors to be liable to the creditors rather, than to the company. So, the law in paper provides for an early information to the creditors. After filing for bankruptcy, often they are even replaced or at least supervised by an appointee of the court. By contrast in US common law the debtor could remain in position (DIP $=$ debtor in possession) and there is no automatic stay, which means that the directors can continue the business and the creditors are barred from rushing to collect. Creditors may, of course, sue afterwards but the assets of the company are not to be frozen in the USA. Generally, the opposite is true in Europe.

This is an important difference. If the creditors are not stopped from collecting after filing bankruptcy, then, instead of a possible reorganisation of an otherwise viable company, the firm may end up in liquidation: the company is not protected from its creditors.

This is even more so when the APR applies. Secured creditors (senior creditors) with absolute priority contracts are first to be satisfied 100\% (in Germany or Sweden) or less (in France) but still in first place (McCormack et al. 2016). More often than not, bank loans are secured contracts, whereas commercial loans are not. Unsecured creditors (junior creditors) are at the rear of the queue, way after employees, tax authorities, landlords, etc. They therefore are not very likely to be able to collect. Hence, they have an interest in reorganisation rather than liquidation, but they have less bargaining power. The outcomes of the laws giving them voting power in a reorganisation plan vary according to the diversity of the stakeholders.

Creditors are ranked, because transactions have prices. The contracting parties may decide how expensive their contracts should be. A secured contract is not at all cheap to draft. The parties (creditors definitely) think the risk is so high that it is worth investing more in drawing up such a contract. The use of standard terms can nevertheless reduce costs. Unsecured contracts are on the other hand cheap and quick contracts; parties feel they are not worth the trouble. The longer the time that elapses between the formation and the performance of the contract, the more likely it is for the parties to require certain securities. 
If creditors are ranked, the classes - into which they are grouped for the purposes of bankruptcy procedures - gain significance. However, if there can be no negotiations about the APR among the creditors, then there is no motivation for the unsecured creditors to approve a reorganisation plan when the company has not enough assets, so again the company faces liquidation instead of reorganisation. Unsecured creditors suffer more of capital insufficiency and information asymmetry, hence a quick partial pay-back is often more crucial for their survival than a lengthy waiting time for a possible more. If the APR may be bargained over, meaning that the secured classes may waive their absolute right for priority satisfaction, then it is more likely that the various classes of creditors will be interested in a possible reorganisation plan with a greater possible pay-back. Furthermore, if a creditor has to pay too high a registration charge for submitting his unsecured claim, then he will not even show up, since there is no point in throwing his money after assets held under a regime that rigidly protects other creditors' interests with APR.

The creditors' majority support is needed to achieve a settlement among the creditors. This majority support is to be based on the value of the claims in a few states in Central and Eastern Europe, e.g. in Slovakia, Bulgaria and in Hungary. In contrast, a decision on such a settlement may be supported by both the majority of the number of the creditors and also the majority based on the value of the claims in the Czech Republic, Poland and Romania.

There are plenty of external costs in the business of a company, so owners are not the ultimate risk bearers as they used to be. The limited liability of shareholders/owners and the separate legal entity of the company makes businesses legally possible at the expense of others. If a financially distressed company files for bankruptcy, the rules allocating the risks are salient, since it is obviously possible that the (remaining) assets of the company will be distributed among its shareholders.

Thus, distribution of the assets may be best prevented by the directors. They have the information on time. Therefore, civil law sanctions apply in most of the countries in Central and Eastern Europe, if directors fail to file for bankruptcy in time and so they cause damages. These are: the Czech Republic, Slovenia and Estonia. Beside civil liability however many countries introduced criminal sanctions too, like Croatia, Bulgaria, Latvia, Poland and Romania. Interestingly enough, these are only Hungary and Slovakia in Central Europe, where there are no such rules. Even more interestingly, however, in case creditors sustained losses as a result of mismanagement of the assets in the jeopardy of the bankruptcy, directors have to compensate the creditors. 
In any event, the biggest problem in the continent is the nature of the liability of the directors and their not being motivated to disclose information early, because in case of bankruptcy they lose control and are removed from their positions. On the other hand, the directors of the SMEs are the owners themselves, so information is definitely at hand. In these cases, these are the creditors - secured or unsecured - who need information desperately in time.

\section{When is it financially advisable to deviate from the APR?}

A special cooperation of the creditors is needed if the coverage (the collateral security) is not enough for all the claims of an otherwise viable debtor. Such settlements mostly require the majority, or even the qualified majority of the creditors or of the creditors representing the majority or qualified majority of the amount of all claims. Therefore, the question is, whether the secured creditors could be motivated to settle not only with the debtor but also with other unsecured creditors, by writing off certain amount of their claims so that to inspire the unsecured creditors too to vote for the settlement. This willingness of the secured creditors to write off some of their claims can be motivated either individually by a renegotiation of the secured contract between the debtor and the creditor or generally by the power of the law. This latter could regulate that in case of a bankruptcy the coverage should not be absolute and prior, rendering APR to be unobserved ipso iure (the carve-out).

The assets of an ailing company are to be divided differently among the various classes of creditors if it is decided in a reorganisation or in a liquidation procedure. During liquidation it is the liquidation value (VL) of the company which is distributed and the APR is observed absolutely. By contrast, in a reorganisation procedure, more often than not, it is inevitable to deviate from the APR so that to achieve a settlement among the creditors and the debtors. The negotiations generate a kind of wealth redistribution in the sense that the debtors could keep their ownership position in the company in exchange to a revaluation of the unsecured debts at the expense of the secured ones. In other words, the secured creditors would not be paid off absolutely prior to the other unsecured creditors thereby leaving a room for manoeuvre to the company management to a restructuring and to a carrying on with the operation.

The objective of a reorganisation procedure is to focus on the further operation of the company. This means that the management still owes a fiduciary duty towards the company. By contrast, in a liquidation procedure the interest of the creditors comes forward and takes over the fiduciary duty of the management towards the company. 
Depending on the bargaining positions of the creditors - and based on equal access to information for all participants -, if liquidation were more advantageous to the owners and the unsecured creditors than the reorganisation, then the secured creditors might be more motivated to negotiate for a settlement in case of a viable company. The unsecured creditors, like suppliers, are often more interested in a quick partial pay off than a lengthy waiting period of hoping for more. Therefore, the deviation from the APR is a fundamental issue in reorganisations.

The efficiency criteria show how the interest of the creditors may be protected in a settlement if one takes the decision with regard to these correlations of $V_{L}>V_{C}$ and the $V_{L}=(1-s) D$ as described above. This however requires the renegotiations of the existing contracts. The question is the ratio between the positive effect of the possible settlement together with the further value producing operation of the company and the costs of the breaching of the APR, i.e. the costs to get creditors with priority be involved in writing off credits (in the hope of a higher return).

A common and significant consequence of the non-observance of the APR is that the shares' pricing rules may get hurt (Senbet \& Wang 2012). This discrepancy steers the behaviour of the investors (owners and creditors) as well as that of the management. Presumed, that the participants act rationally and are all well informed, and may calculate the occurring probability of the non-observance of the APR, the costs of this probable incidence will be part of the price (Eberhart \& Weiss 1998). If the breach of the APR is more advantageous for the shareholders and its probability is built in their expectations, then this would generate a lower profit for them. By contrast, the secured creditors in the front of the debt queue would expect higher yield in exchange for the higher risk in this case. The real question is therefore, whether this kind of market re-pricing, due to the breach of the APR in the bankruptcy procedure of the financially distressed companies, could work for every market actor unhinged.

Beside the calculation of the occurring possibilities however, one has to focus also on the degree of these deviations from the APR. From the creditors' point of view, unless the costs of the bankruptcy are lower than the premium (surcharge) which is to cover the costs of the risk of the bankruptcy, the deviation would not have impact on the pricing of the financial products (Longhofer \& Carlstrom 1995). This would practically mean, that until then, the expected yield of the creditor, or the interest rate on the loan, will not change, will not be higher and, vice versa, it will not be lower for the debtor. On the contrary, if the degree of the deviation would be costlier than the costs of the bankruptcy, then the interest rate of the loan would increase ex 
ante for the creditor and the expected yield of the owner/debtor would at the same time decrease constraining thereby the investment possibilities of the company.

So, in the course of negotiation about the deviation from the APR one focuses on the optimal position of the participants of the company (Baird 2016). And no doubt, this deviation comes with a price. Obviously, the APR is a very important instrument for providing credit, therefore its breach or a renegotiation in the bankruptcy procedure will have even ex ante impact on the financing costs of the company.

Truly a deviation from the APR may result in a positively effective reallocation of company assets so that the shareholders keep their investment in the restructured company, the creditors undertake the refinancing and the strategic suppliers (generally the non-secured creditors) support the company as a going concern, etc. None of these potential benefits should veil the fact that any deviation from the APR comes at a price which is to be calculated at the time of deciding on the creditors' settlement.

Therefore, a settlement for reorganisation - and thereby a deviation from the APR - is to be supported unless and until the degree of the deviation would result in a pricing change of the value producing companies in the financial markets (at the expense of the minority shareholders in the ailing companies).

\section{THE CASE OF THE HUNGARIAN PRIMARY RESEARCH 2009-2017}

\section{Hungarian bankruptcy amendments and the data of the empirical research}

These were also the salient questions of the primary research carried out after the global crisis in Hungary. The basic issue is that there is no clear shift in the reorganisation data after the new rules on reorganisation were introduced in 2009. Although these rules are seemingly in line with the international standards in reorganization matters (law in paper), still there is no such efficient capital allocation as should have been expected by the investors and would have been necessary to reinforce the trust in the market (law in action). Or in other words, why could not get Hungary further up to the front in the World Bank ranking?

The Act No. LI of 2009 in Hungary, amended the then existing bankruptcy rules and promoted reorganisation procedures as opposed to liquidation. But the intent to reinvigorate the institution of bankruptcy in general met only accidentally with the aim of the globally enhanced preferences. This provision was a result of a more than a decade long debate during the transition from the socialist command market to a free market. The first step, back then, was to introduce a uniquely strict automatic bankruptcy law as a response to the reluctance of the 
companies to file for bankruptcy or liquidation (Act No XLIX of 1991). The rules therein on promoting automatic stay which could help creditors' settlement (collateral settlement) were withdrawn in 1993, since then companies in financial distress systemically faced liquidation. This practice was to be changed to promote reorganisation in 2009 again (Act No. LI of 2009). The priority of the reorganisation procedure over liquidation was declared anew, an automatic stay rule (immediate moratorium) was reintroduced.

Our primary research in 2014 provides information from (i) the Budapest-Capital Regional Court and (ii) the Amadeus database29. The Court collects data on bankruptcy and liquidation separately in addition to the records on the cases which ended with a settlement too. It has to be noted that this sample is not representative, therefore to ensure the random selecting, the Court was requested to allow us to study the cases of only one judge at the Court. Since the cases are assigned randomly among the competent judges at the Court, we recognized this as representability.

Table 2 The various filings for reorganisation at the Budapest-Capital Regional Court, depending on how they ended (2009-2014)

\begin{tabular}{|c|c|c|c|c|}
\hline \multicolumn{2}{|c|}{$\begin{array}{c}\text { End of the procedure in filings for } \\
\text { reorganisation }\end{array}$} & \multicolumn{2}{|c|}{ Number of cases } & \multirow{2}{*}{$\begin{array}{c}\begin{array}{c}\% \text { of } \\
\text { filings }\end{array} \\
\text { Total-pool }\end{array}$} \\
\hline & & Total-pool & $\begin{array}{c}\text { Small- } \\
\text { pool }\end{array}$ & \\
\hline \multicolumn{2}{|c|}{ Settlement /Agreement } & 79 & 34 & $27 \%$ \\
\hline \multicolumn{2}{|c|}{ Liquidation } & 167 & & $58 \%$ \\
\hline \multirow{3}{*}{$\begin{array}{l}\text { Refusa } \\
1\end{array}$} & Documents not completed & 21 & 17 & $7 \%$ \\
\hline & Previous iquidation & 10 & 10 & $3 \%$ \\
\hline & Termination of procedure & 5 & 4 & $2 \%$ \\
\hline \multicolumn{2}{|c|}{ Other termination } & 6 & 6 & $2 \%$ \\
\hline \multicolumn{2}{|l|}{ Total } & 288 & 71 & $100 \%$ \\
\hline
\end{tabular}

Sources: Budapest-Capital Regional Court data

As seen in Tab. 1., out of the 332 cases 83 were closed with a creditors' settlement. The Court refused to approve the settlement in 182 cases which triggered the automatic liquidation procedure. At the time of the research, there were 288 closed reorganisation procedures and 19 still in-process, out of the 307 under scrutiny. The identification of the 97 companies was also unsuccessful in some cases: only 71 were found in Amadeus.

The question was: how did the companies with a creditors' settlement make deliberative, information-based decisions for an effective reallocation of the company assets capable to further operation. The scrutiny was two pronged: firstly, based on historic parameters, we

\footnotetext{
${ }^{29} \mathrm{https}$ ://amadeus.bvdep.com/
} 
analysed the companies' value producing capability, and their debt leverage (indebtedness) as well as the legal reason for the filing for a bankruptcy and their liquidity problems. Secondly, based on future expectations, we studied the value-producing reorganisation plans of these companies at the Court.

The historic data indispensable in our research for these companies are not listed in the stock markets. 288 companies were identified in the Amadeus Database, out of the 332 having filed for bankruptcy at the Court, and so had their financial statements and balance sheets available providing us the chance to investigate the necessary company data during the years before the filing the petition with the Court. According to our working hypothesis, and lacking market information, those companies were to have the capacity to make profit, which had been capable to do that earlier too or at least to cover their accounting expenses out of their income. We presumed that the financial difficulties were an outside impact on them which would therefore be eliminated by credit restructuring or by managing the preliminary lack of liquidity. Even if a company was not capable to survive at first glance, it still could have the chance to reorganisation, if it had elabourated reorganisation plan to enter into a value producing phase.

Surprisingly, the historic data showed no difference in equipment effectiveness, capital leverage or liquidity of the differently positioned companies. There was absolutely no evidence of deliberating the possibility of a reorganisation plan.

A rational market participant makes decisions based on future expectations, which require a sufficient level of convincing prediction about the revitalization ability of these companies. Yet there was no reorganisation plan at all in any of these reorganisation or settlement procedures. The only issue at hand during the negotiations was the swiftest possible repayment of the creditors which, from a financial point of view, fundamentally undermines any reorganisation plan.

Clearly, the goals of the new laws on the reorganisation plan did not work. If the aim was to elaborate a plan how to re-establish the liquidity of a company for continued short-term operation with due regard to the market environment and the company's potentials, then it was plainly not working. This included the lack of plans for the collecting of receivables and the sale of assets without jeopardizing the short-term financing of operations to be continued. Neither were the portfolio services adjusted to the (new future) market expectations and the long-term financing of the company needs. Nor were there plans to ensure the resources for the restructuring company or any optimization of the capital leverage. There was simply no reorganisation plan to indicate how to reach a profitable company structure efficiently and whether to sell the assets of the company in total or piece by piece. 


\section{APR and efficient protection of the creditors}

Having found this lack of deliberation we studied the parameters (on protecting creditors), the repayment rates and the validity of the APR. As for a first glance it may be fixed, that the new laws of 2009 did have an impact on the repayment rate of the creditors.

Table 3 The number of newly filed bankruptcy cases

\begin{tabular}{|l|r|r|r|}
\hline & $\mathbf{2 0 0 8}$ & $\mathbf{2 0 1 0}$ & $\mathbf{2 0 1 7}$ \\
\hline Number of bankruptcy cases & 2 & 123 & 39 \\
\hline Number of liquidation cases & 9800 & 11269 & 6469 \\
\hline Operating and registered companies & & & \\
& 443222 & 481911 & 529608 \\
\hline
\end{tabular}

Sources: Budapest-Capital Regional Court data

However, one has to be cautious with this statement too, since statistically, before 2009 there had been only a very few cases of bankruptcy procedures. Again, basically, this has been the very reason which lead to the amendment of the Act on Bankruptcy Procedures. So, the repayment rate of $1.58 \%$ registered within the liquidation procedures, soared to the $43.7 \%$ in the reorganisation procedures with settlement.

But this should come as no surprise. According to the parameters a settlement is not an alternative for a company which had reached the critical status of $V=0$ instead of the $V=D$, in which case there might be no chance of an efficient last-minute reorganisation. The majority of all companies under scrutiny had already been losing assets $(\mathrm{V}<\mathrm{D})$ before filing for bankruptcy regardless of whether they had made a settlement or were heading for liquidation. The better repayment rate shows therefore, that the chances for a reorganisation of the company is higher in a bankruptcy procedure at the time of filing for bankruptcy.

Now, let us see the validity of the APR. The key issue here is, whether and to what degree the debtor and the secured creditors could agree on the amount of the claim to be written off. In so calculating, the secured creditors define their value of contribution so that the remaining claims, (1-s)D, be equal with the liquidation value, VL, valid in the event of immediate liquidation. After the bankruptcy amendment of 2009 in Hungary, as the results of the primary research show, this calculus is as follows:

1. The observance of the APR was not to be analysed

(i) either because there were no secured creditors at $22.58 \%$ of the companies with settlement,

(ii) or because there were no registered unsecured creditors at $9.68 \%$ of the companies with settlement. 
2. The deviation from the APR was evidenced in $54.1 \%$ of the cases of the companies with settlement: the secured creditors were not repaid in $100 \%$ but the non-secured creditors were partially repaid.

3. There was no deviation from the APR in $28.8 \%$ of the cases of the companies with settlement: the secured creditors were paid up fully, $100 \%$.

It should be noted here, that in compliance with most of the European legal regimes, the Hungarian laws apply the carve out system too, but its degree changes too often $(25 \%, 50 \%)$, so it is hard to compare the efficiency in this regard.

Beside the frequency of the deviation from the APR it is the degree of this deviation that matters the most. It is well established, that the salient impact on the repricing of the stock market depends rather on the degree of the deviation from the APR in proportion to the value of the company and not on the frequency of the deviation. This deviation has two-pronged influence on the companies' life. Firstly, a significant deviation from the APR impacts also the capital costs. Secondly, the deviation from the APR motivates the unsecured creditors to support the creditors' settlement in case of a viable but bankrupt company.

In addition to the benefit of the deviation from the APR, both creditor groups are repaid within an average of 260 days. This means a further actual over-preferencing of the non-secured creditors at the expense of the secured creditors. Obviously, the secured creditors could not keep their privileged status, not even in the timing of the repayment.

\section{The aftermath of the research}

The data on the repayment ratio are based on the creditors' settlements and reflect the expectations of the Court. The average of the final repayment date for all creditors, either secured or non-secured, is the $260^{\text {th }}$ day calculated from the day of entering into the settlement. These results trigger a tension, an incoherence in what we have found and demonstrated in our research: if it is showed, as we did, that the settlements are usually made in an ill-informed manner by the participants of the bankruptcy procedure, then the settlement cannot serve the rational bases for the protection of the creditors. Then how to explain the ameliorating tendency of the repayment of the claims?

The following table shows the real after life of the companies with settlements (Table 4.). 
Table 4 Status of companies filing for bankruptcy (2009-2014) with the Budapest-Capital Regional Court according to data registered at 2013 and checked in Amadeus

\begin{tabular}{|c|c|c|c|c|c|c|c|}
\hline Statu & of companies & $\begin{array}{c}\text { No /Co's } \\
\text { with } \\
\text { settlement in } \\
\text { Amadeus }\end{array}$ & $\begin{array}{l}\text { Rate/Co's } \\
\text { with } \\
\text { settlement in } \\
\text { Amadeus }\end{array}$ & $\begin{array}{l}\text { No /Co's } \\
\text { without } \\
\text { settlement } \\
\text { (liquidated } \\
\text { Co's) in } \\
\text { Amadeus }\end{array}$ & $\begin{array}{l}\text { Rate/Co's } \\
\text { without } \\
\text { settlement } \\
\text { (liquidated } \\
\text { Co's) in } \\
\text { Amadeus }\end{array}$ & $\begin{array}{c}\text { No/Co's with } \\
\text { settlement in } \\
\text { data } \\
\text { collected at } \\
\text { the Court }\end{array}$ & $\begin{array}{l}\text { Rate /Co's with } \\
\text { settlement in } \\
\text { data collected at } \\
\text { the Court }\end{array}$ \\
\hline & Active & 3 & 0.04 & 14 & 0.08 & 1 & 0.03 \\
\hline Active & $\begin{array}{l}\text { Active (in } \\
\text { insolvency } \\
\text { proceedings) }\end{array}$ & 31 & 0.39 & 34 & 0.20 & 17 & 0.49 \\
\hline Active & $\begin{array}{l}\text { "Active" } \\
\text { others (in } \\
\text { liquidation, } \\
\text { dissolved) }\end{array}$ & 3 & 0.04 & 8 & 0.05 & 1 & 0.03 \\
\hline Non- & $\begin{array}{l}\text { Active } \\
\text { (dormant) }\end{array}$ & 30 & 0.38 & - & - & 13 & 0.37 \\
\hline & Bankruptcy & 12 & 0.15 & 111 & 0.66 & 3 & 0.09 \\
\hline Total & & 79 & 1.00 & 167 & 1.00 & 35 & 1.00 \\
\hline
\end{tabular}

Sources: Amadeus database and the Official Gazette

This demonstrates that nearly half (47\%) of the 79 companies with settlement could survive the first 3 years following the reorganisation according to the data from the Amadeus database. Notwithstanding, the number of the companies still active after 3 years following the reorganisation is only 3. The most interesting group of companies is the "active (dormant)" category, the companies of which are registered as active in the Company Register but has no activity at all.

These data were also supported by the primary research presented above. There was only 1 company in the "active" category out of the 35 companies with settlement 3 years after the filing for bankruptcy. $37 \%$ of the companies with settlement ended up in the "active (dormant)" category. Almost half of the companies with settlement are non-operating after 1-3 years following the filing for bankruptcy.

These findings show conspicuously that the high repayment expectations in the creditors' settlements are not fulfilled. The majority of the companies with settlement become either nonoperating or liquidated. This is also clear, that the new bankruptcy regulations of the global crisis grant neither an efficient reallocation in the reorganisation procedure nor a better rate of claims repayment by the deviation from the APR. These results are mirrored in the decreasing numbers of the filing for bankruptcies with the bankruptcy courts in a period between 2008 and 2017. 


\section{EFFICIENCY OF THE HUNGARIAN BANKRUPTCY RULES IN THE EU CONTEXT}

The rational beyond the shift in the regulation in Hungary, was that in the case of a financially distressed company a flexible reorganisation procedure should ameliorate, complement replace or forestall, if needed - the bankruptcy procedures resulting in liquidation. Yet, the primary research analysed in this article shows that not even the breach of the APR provides for a better environment for the settlement. Generally, all companies with such a settlement in the research ended up, after a few years, in a liquidation procedure or remained dormant in a non-active status. Thus, in Hungary, systemically, reorganisations do not set up value producing viable companies.

Clearly, these problems do not root in the regulations: bankruptcy laws do comply with the EU regulations and the international standards (Boon 2018; Blazy, Petey, \& Weill, 2018; McCormack, 2017). The reasons for this system failure - according to the primary research, are rather (i) the structure of the financial/credit market, (ii) the overwhelming majority of the SMEs as opposed to companies listed in the stock market and (iii) the nature of the credit for the SMEs.

The Hungarian financial market is bank-based market. Market participants seldom collect money from the public through the stock market. In fact, the setting up of a public company directly in the stock market is illegal (Civil Code 3:249. §).

In our research we have found that almost half of the companies in the bankruptcy procedure lacked secured credits, which means that these companies had no bank loans at all. These debtors faced commercial creditors, consumers, tax payers or simply employees. These commercial creditors, often in financial distress themselves too, cannot make settlements, especially, because for them often there is no information in hand whatsoever. The bank-based financial markets are not too transparent, but a market full with SMEs, is even more blur. Because of the big numbers of the SMEs in the market and often because of the lack of capacity to understand financial risks from the commercial creditors' or the employees' part, the rational basis of a creditors' settlement is far from realistic.

Therefore, the amended Hungarian bankruptcy laws in compliance with the EU regulation could not guarantee a better ranking for the country. As is seen in Graph 1, the efficiency of the bankruptcy rules in Hungary provides only the $24^{\text {th }}$ place among the 28 Member States, far below the EU average. Clearly, the law in paper is not what the law in action is. 


\section{Figure 1}

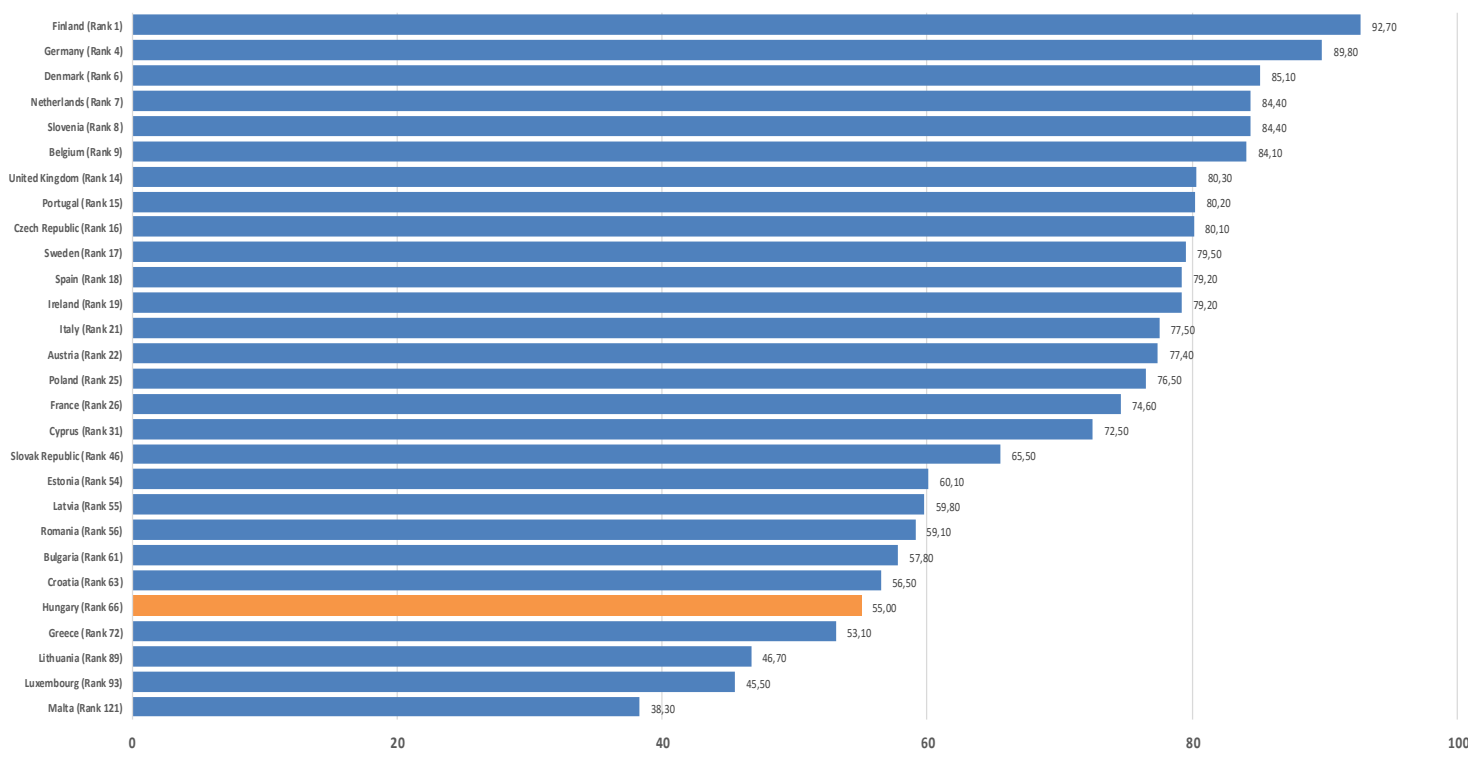

Source: Doing Business database 2019.

\section{CONCLUSION}

The main statement of the article is that the Hungarian bankruptcy rules fail to promote the efficient capital allocation because the stakeholders have no information or are not interested for the costs may be too high - in those financial data or parameters, which are necessary for a deliberated settlement in a bankruptcy procedure. As a last resort, the deviation from the absolute priority rule (APR) may motivate the different classes of the creditors to enter an agreement on reorganisation. Yet, the primary research analysed in this article shows that not even a deviation from the APR provides for a better environment for the settlement so that to save a value producing viable company. Generally, all companies with such a settlement in the research ended up, after some years, in a liquidation procedure or remained dormant in a nonactive status.

The rules in Hungary as shown do not differ from those of other countries in the region. Yet, the results are not what are wished for. So, practically a troubled company needs to be liquidated and the creditors be paid up as soon as possible.

Since the information is hard to acquire and the actors of the bankruptcy procedure do not cooperate, even if it were better for them, the authors suggest a completely different approach and a different procedure as a solution to the problem. The aim of the rules should not be the coercion of the cooperation but the opposite: let one creditor have the chance to reorganise the company as soon and as quick as it is possible. One decision-maker could gather the necessary data and could decide swiftly. A possible procedure for this may be the automatic bankruptcy auctions as applied in the Swedish model. 


\section{REFERENCES}

Ábel, I. (1991). A csőd árnyalatai. Közgazdasági szemle, 38(11), 1058-1071.

Baird, D. G. (2016). Priority matters: absolute priority, relative priority, and the costs of bankruptcy. U. Pa. L. Rev., 165, 785.

Blazy, R., Petey, J., \& Weill, L. (2018). Serving the creditors after insolvency filings: from value creation to value distribution. European Journal of Law and Economics, 45(2), 331375.

Boon, G. J. (2018). Harmonising European Insolvency Law: The Emerging Role of Stakeholders. International Insolvency Review, 27(2), 150-177.

Cirmizi, E., Klapper, L., \& Uttamchandani, M. (2010). The challenges of bankruptcy reform. The World Bank.

Claessens, S., \& Laeven, L. (2005). Financial dependence, banking sector competition, and economic growth. Journal of the European Economic Association, 3(1), 179-207.

Correa, P., \& Iootty, M. (2010). The impact of the Global Economic crisis on the corporate sector in Europe and central Asia: Evidence from a Firm-level survey. Enterprise Surveys Enterprise Note Series. EU, 10.

Demirguc-Kunt, A., Laeven, L., \& Levine, R. (2003). Regulations, market structure, institutions, and the cost of financial intermediation (No. w9890). National Bureau of Economic Research.

Eberhart, A. C., \& Weiss, L. A. (1998). The importance of deviations from the absolute priority rule in chapter 11 bankruptcy proceedings. Financial Management, 106-110.

Eckbo, B. E., \& Thorburn, K. S. (2009). Economic effects of auction bankruptcy. Tuck School of Business Working Paper, (2009-63).

Goolsbee, A. D., \& Krueger, A. B. (2015). A retrospective look at rescuing and restructuring General Motors and Chrysler. Journal of Economic Perspectives, 29(2), 3-24.

Haugen, R. A., \& Senbet, L. W. (1978). The insignificance of bankruptcy costs to the theory of optimal capital structure. The Journal of Finance, 33(2), 383-393.

Holmes, O. W. (1897). The Path of the Law, 10 Harv. L. Rev, 457.

Klapper, L., Laeven, L., \& Rajan, R. (2006). Entry regulation as a barrier to entrepreneurship. Journal of financial economics, 82(3), 591-629.

Longhofer, S. D., \& Carlstrom, C. T. (1995). Absolute priority rule violations in bankruptcy. Economic Review-Federal Reserve Bank of Cleveland, 31, 21-30.

McCormack, G., Keay, A., Brown, S., \& Dahlgreen, J. (2016). Study on a new approach to business failure and insolvency. Comparative Legal Analysis of the Member States 'Relevant Provisions and Practices. Luxembourg: Publications Office of the European Union.

McCormack, G. (2017). Business restructuring law in Europe: making a fresh start. Journal of Corporate Law Studies, 17(1), 167-202.

Miller, M., \& Stiglitz, J. (1999, April). Bankruptcy protection against macro-economic shocks: the case for a 'super chapter 11'. In World Bank Conference on Capital Flows, Financial Crises, and Policies (Vol. 15).

Senbet, L. W., \& Wang, T. Y. (2012). Corporate financial distress and bankruptcy: A survey. Foundations and Trends ${ }^{\circledR}$ in Finance, 5(4), 243-335.

White, M. J. (1983). Bankruptcy costs and the new bankruptcy code. The Journal of Finance, $38(2), 477-488$.

Temporary framework (2008). for Member States to tackle effects of credit squeeze on real economy. IP/08/1993, Brussels Retrieved from http://europa.eu/rapid/press-release_IP08-1993_en.htm?locale $=$ en 